\title{
大蒜植物络合素合酶基因转化对酵母 重金属抗性的提高
}

\author{
姜瑛楠 冯保民 张海燕 麻 密* \\ (中国科学院植物研究所光合作用与环境分子生理学重点实验室, 北京 100093)
}

\begin{abstract}
摘 要 重金属污染是全球面临的亟待解决的生态问题。利用植物对重金属的富集作用来清除环境重金属污染 即植物修复已成为重要的环境生物技术之一。这一技术的长远发展有赖于在重金属富集或耐受中起关键作用的 基因的克隆和应用。植物络合素是植物体内一类重要的对重金属起螯合作用的多肽, 其合成受植物络合素合酶的 催化。该文取得了如下研究结果: 1) 通过原子吸收测定表明, 在大蒜( Allium sativum) 的根部可以积累 $3000 \mathrm{mg} \cdot \mathrm{kg}^{-1}$ 的重金属镉; 2 ) 将克隆的大蒜植物络合素合酶基因 ( $A s P C S$ ) 置于酵母表达启动子之下, 构建酵母表达载体, 并将其 分别转入了因 $C U P 1$ 和 $a c r 3$ 基因缺失而对重金属镉和砷敏感的酵母突变体菌株后, 发现来自大蒜的 $A s P C S$ 基因的 表达使酵母 CUP 1 缺失菌株对镉的耐受性提高了 4 倍, acr3 缺失菌株对砷的耐受性提高了两倍; 3 )表达 AsPCS 基因 酵母的生长模式证实了 $A s P C S$ 基因的表达是酵母对重金属耐受性提高的原因。这些结果暗示, 大蒜植物络合素合 酶基因在大蒜对重金属的抗性及大蒜根部对镉的积累中起关键作用,可作为重要的基因元件应用到修复污染的植 物基因工程中。
\end{abstract}

关键词 植物络合素合酶基因 植物修复 重金属抗性 大蒜

\section{IMPROVING HEAVY METAL TOLERANCE OF YEAST BY TRANSFERRING A PHYTOCHELATIN SYNTHASE GENE FROM GARLIC}

\author{
JIANG Ying-Nan, FENG Bao-Min, ZHANG Hai-Yan and MA Mi* \\ ( Key Laboratory of Photosynthesis and Environmental Molecular Physiology, Institute of Botany, Chinese Academy of Sciences, Beijing 100093, China)
}

\begin{abstract}
Remediation of soils contaminated by heavy metals is one of the most pressing environmental problems facing the biosphere. Phytoremediation is a new biotechnique to clean environmental pollutants by plants, including heavy metals. In the long term, major improvements in phytoremediation will rely on the isolation and application of the genes from various plant, bacteria, and animal sources that can enhance metal accumulation. Phytochelatin is a type of polypeptide that combines heavy metals in plants, and its synthesis is regulated by phytochelatin synthesase ( PC synthase). In this study, we determined that the roots of garlic (Allium sativum ) can accumulate up to $3000 \mathrm{mg} \cdot \mathrm{kg}^{-1}$ cadmium. A yeast-expressed plasmid with PC synthesase from garlic $(A s P C S)$ was constructed and transferred into heavy metal sensitive yeast mutant cells. The results showed that the expression of $A s P C S$ was improved by 4 folds in yeast cells with cadmium tolerance and a 2 folds increase was observed in arsenate tolerant cells as compared to the control cells. Further study about the growth patterns of $A s P C S$-expressed yeast indicated that the expression of $A s P C S$ was critical for yeast heavy metal tolerance. As an important role in the garlic's response to heavy metal, $A s P C S$ can work as a significant gene tool in the phytoremediation of heavy metal pollution.
\end{abstract}

Key words Phytochelatin synthase gene, Phytoremediation, Heavy metal tolerance, Garlic

Heavy metal pollution has become one of the most serious environmental problems worldwide. Due to the non-degradable nature, heavy metals infiltrate into organisms through food chain and cause health problems. For example, $\mathrm{Cd}^{2+}$ displaced $\mathrm{Ca}^{2+}$ or $\mathrm{Zn}^{2+}$ in proteins and caused oxidative stress ( Stohs \& Bagchi, 1995; Goyer, 1997). Arsenate, as a phosphate analog, disrupted phosphate metabolism, and arsenite reacted with the sulfhydryl groups of enzymes and tissue proteins, leading to inhibition of cellular function and death (Meharg \& Hartley- 
Whitaker, 2002).

Remediation of soil contaminated by heavy metals is one of the most pressing environmental problems facing the biosphere. Some plants can accumulate much more heavy metals from soils than others. The leaves of Pteris vittata could hyper-accumulate over 1000 -fold higher arsenate than normal plant ( Ma et al., 2001; Wei \& Chen, 2002). Phytoremediation is an emerging technique to clean environmental pollutions that include heavy metals by such plants. Two major metabolism mechanisms for plants to remove environmental heavy metal pollution were found: one was phyto-extraction in which heavy metals were extracted from polluted sites by plant roots, then transported to the shoots and subsequently harvested just as Sesbania rostrata whose stem nodule could accumulate more heavy metals (Jian \& Yang, 2002); the other was phyto-stabilisation in which heavy metals were immobilized by some complexes in plants, generally in combination with heavy metal binding proteins. Major improvements in phytoremediation in long term relied on the isolation and application of the genes from various plants, bacterium, and animals, which could enhance the metal accumulation (Salt et al., 1998).

Phytochelatin was one of the major heavy metal binding proteins. It was synthesized from GSH by the catalysis of phytochelatin synthase (PC synthase) (Rauser, 1999; Zhang et al., 1999). PC synthase genes were first cloned from Arabidopsis, wheat and yeast (Clemens et $a l ., 1999$ ). Some studies proved that they played important roles in the plant response to heavy metals. So further investigation about the characteristic of PC synthase genes was critical for the phytoremediation to heavy metal pollution.

However, the research about the PC synthase genes so far is focused on the heavy metal sensitive plants. The characteristic of PC synthase genes in heavy metal resistance plants that are major tools for phytoremediation is still unclear. Garlic ( Allium sativum) plant shows higher tolerance for heavy metals than other plants. The PC synthase gene from garlic $(A s P C S$ ) has been cloned (GenBank Accession No. AF384110), and we are interested in understanding the function and the potential use of PC synthase gene from this metal resistant plant. Yeast contains CUP 1 and acr 3 gene that are required for copper and arsenite tolerance (Zhou \& Goldsbrough, 1994; Wysocki et $a l ., 2003$ ), respectively. The CUP1 mutant (ABDE-1) and acr3 mutant (FD236-6A) are highly sensitive to copper, cadmium and arsenic, so these mutants are appropriately used to test the function of heavy metal tolerant genes. Here, we report the improvement of the yeast cell' $\mathrm{s}$ heavy metal tolerance by expressing the $\mathrm{PC}$ synthase gene from garlic.

\section{Materials and methods}

\subsection{Plant materials}

Seedlings were developed from cloves of garlic in polyethylene pots with $2 \mathrm{~kg}$ clean sand. The experiment was carried out under greenhouse conditions. All pots were poured with distilled water. After 3 weeks, the plants were treated with $1,2,5,7$ and $10 \mathrm{mmol} \cdot \mathrm{L}^{-1}$ $\mathrm{CdCl}_{2}$ solution for $8 \mathrm{~d}$ and harvested at each sample date for analysis.

\subsection{Yeast strains and vectors}

Saccharomyces cerevisiae ABDE-1 ( arg4-8, leu2112, his7-2, trp 1-289, ade5, and cup 1) is sensitive to copper and cadmium (Ecker et al., 1986), while FD236-6A (MATa, ura3-52, trp 163, leu21, his3200, acr3-1: : URA3 GAL2) (Wysocki et al ., 1997) is sensitive to arsenic. The vector pFL61 contains the phosphoglycerate kinase ( PGK) promoter and terminator (Minet et al., 1992). Saccharomyces cerevisiae cells were grown in YPD medium.

\subsection{Determination of cadmium}

Plants were collected from the sand carefully, washed thoroughly with running distilled water, divided into leaves and roots and dried to a constant weight. 300 mg dry samples were digested with a mixture of $\mathrm{HNO}_{3}$ and $\mathrm{HClO}_{4}(10: 1, \mathrm{v} / \mathrm{v})$. Cd was determined by ICP-AES ( Inductively coupled plasma-atomic emission spectroscopy) with a standard method.

\subsection{Construction of yeast expression vector}

The pFL61 yeast expression vector was digested by the enzyme of Bst XI, whose restriction site lies between the PGK promoter and terminator. In order to add the Bst XI cut site on both sides of AsPCS, a pair of primers, GCCAGTGTGATGGATGGTACGATGGAAGGAT and CCAGTGTGCTGGAGTAAGTATGTGAATTTTG, was used to perform a PCR with 5 circles of $1 \mathrm{~min} 95{ }^{\circ} \mathrm{C}, 1 \mathrm{~min}$ $45{ }^{\circ} \mathrm{C}$, and $90 \mathrm{~s} 72{ }^{\circ} \mathrm{C}$ followed by another 30 circles of 1 $\min 95{ }^{\circ} \mathrm{C}, 1 \min 65{ }^{\circ} \mathrm{C}$, and $90 \mathrm{~s} 72{ }^{\circ} \mathrm{C}$. The products were digested by Bst XI and ligated into the vector. The expressing vector was named $\mathrm{pFLAsPCS}$.

\subsection{Yeast transformation and growth pattern}

Yeast of ABDE-1 and FD236-6A were transformed separately with pFLAsPCS following the protocol in the Yeast Protocols Handbook, Clontech PT3024-1 (1997). Transformants were selected using a 1/2 solid YPD plate containing either $5 \mu \mathrm{mol} \cdot \mathrm{L}^{-1} \mathrm{CdCl}_{2}$ ( for ABDE-1) or 20 
$\mu \mathrm{mol} \cdot \mathrm{L}^{-1} \mathrm{NaAsO}_{2}$ ( for FD236-6A). Transformants were grown overnight in liquid YPD and diluted to the density of $\mathrm{OD}=0.45$ at $600 \mathrm{~nm}$. Ten $\mu \mathrm{l}$ of these cell suspensions were added to $20 \mathrm{ml}$ of fresh liquid YPD containing increasing concentrations of $\mathrm{NaAsO}_{2}$ or $\mathrm{CdCl}_{2}$. The cultures were incubated at $28{ }^{\circ} \mathrm{C}$ with vigorous shaking, and the absorbance at $600 \mathrm{~nm}$ was measured after 24 and $48 \mathrm{~h}$ (Wysocki et al., 1997).

\section{Results}

2.1 Cadmium distribution in roots and shoots of garlic

The cadmium in the roots and shoots of garlic treated with Cd was measured by atomic absorption spectrometry . The results showed that the $\mathrm{Cd}$ concentration increased in both roots and shoots when treated by more cadmium or longer time. The roots accumulated much more cadmium than the shoots. After 6 days being treated with $10 \mathrm{mmol}$ $\mathrm{L}^{-1} \mathrm{CdCl}_{2}$, the $\mathrm{Cd}$ in the roots increased to $3000 \mathrm{mg} \bullet$ $\mathrm{kg}^{-1} \mathrm{DW}$, while the $\mathrm{Cd}$ in the shoots was only $26 \mathrm{mg} \bullet$ $\mathrm{kg}^{-1}$ DW (Fig. 1).

2.2 Growth of the transformed yeast cells with AsPCS on metal plates

To investigate whether AsPCS expression can cause a dramatic increase in $\mathrm{Cd}^{2+}$ and $\mathrm{AsO}_{2}{ }^{-}$tolerance, plasmid containing the whole ORF of $A s P C S$ was transformed to Saccharomyces cerevisiae cells. The transformed yeast cells were streaked on plates with different concentrations of $\mathrm{Cd}^{2+}$ and $\mathrm{AsO}_{2}{ }^{-}$. As shown in Fig. 2A, the yeast cells of ABDE-1 expressing the PC synthase gene from garlic $(A s P C S)$ can grow on the plate which contains 35 $\mu \mathrm{mol} \cdot \mathrm{L}^{-1} \mathrm{CdCl}_{2}$, whereas the control cells tend to be dead on the plate which contains $10 \mu \mathrm{mol} \cdot \mathrm{L}^{-1} \mathrm{CdCl}_{2}$.
These results indicated that the $\mathrm{Cd}^{2+}$ tolerance of ABDE1, a cup 1 mutant of Saccharomyces cerevisiae sensitive to cadmium, improved 3-fold more after expressing AsPCS . From Fig. 2B, we can see that the FD236-6A cells expressing the AsPCS gene can stand against $700 \mu \mathrm{mol} \cdot \mathrm{L}^{-1}$ $\mathrm{AsO}_{2}{ }^{-}$on agar plate, whereas the control cells cannot grow on the plate containing $300 \mu \mathrm{mol} \cdot \mathrm{L}^{-1} \mathrm{AsO}_{2}{ }^{-}$. It was shown that FD236-6A, which sensitive to arsenic, could improve the arsenic tolerance by expressing the $A s$ $P C S$ gene from garlic.

2.3 Growth pattern of the transformed yeast cells with AsPCS in liquid medium containing different heavy metals

Contrasting to complete inhibition for the control cells, AsPCS-expressed yeast cells grew well in liquid YPD in the presence of $\mathrm{Cd}^{2+}$ or $\mathrm{AsO}_{2}{ }^{-}$. AsPCS-expressed cells gave almost normal growth pattern in medium containing $0.01 \mathrm{mmol} \cdot \mathrm{L}^{-1} \mathrm{Cd}^{2+}$ when compared with the control yeast growing in normal medium, while the control yeast died quickly in the medium containing $0.01 \mathrm{mmol}$ $\mathrm{L}^{-1}$ cadmium (Fig. 3A). Similar results were also observed in the AsPCS-expressed yeast cell growing in the $\mathrm{AsO}_{2}{ }^{-}$contained medium (Fig. 3B).

After growing in liquid YPD for $24 \mathrm{~h}$, the AsPCSexpressing cells showed higher biomass than the control in different heavy metal concentrations ( Fig. 4). For FD236-6A, the biomass of AsPCS-expressing cells in 300 $\mathrm{mmol} \cdot \mathrm{L}^{-1}$ arsenite, in which the control cells were almost completely inhibited, decreased to $45 \%$ of the cells in liquid YPD, and they were completely inhibited in 600 $\mathrm{mmol} \cdot \mathrm{L}^{-1}$ arsenite (Fig. 4A); for ABDE-1, the biomass of $A s P C S$-expressing cells in $5 \mu \mathrm{mol} \cdot \mathrm{L}^{-1}$ cadmium, in which the control cells were completely inhibited,
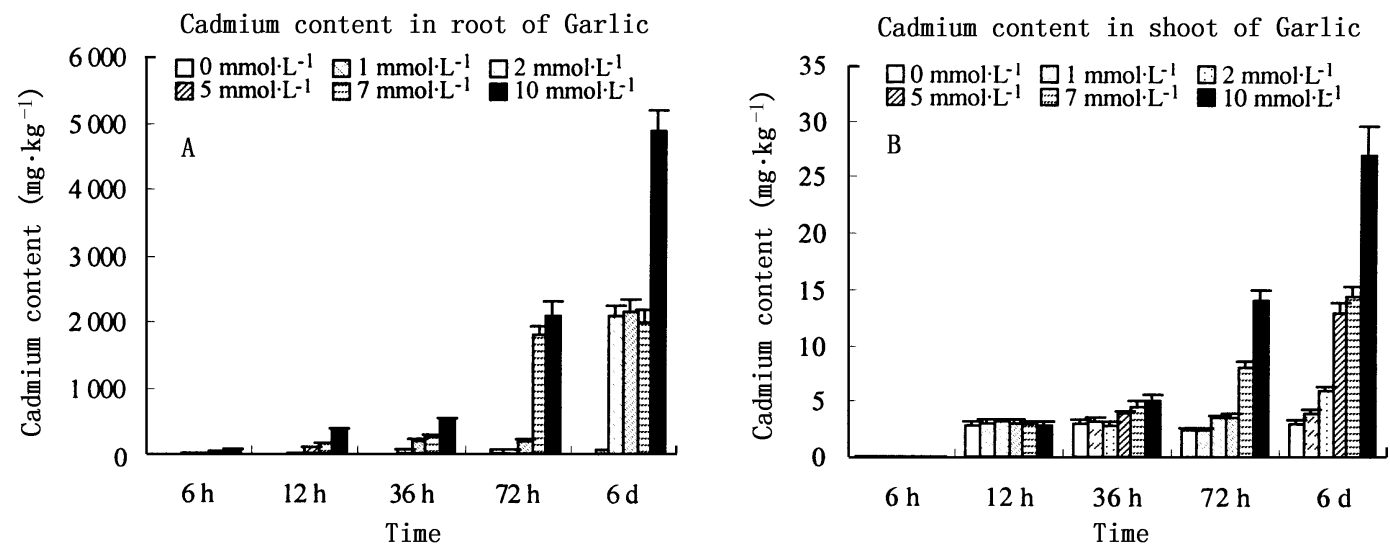

Fig. 1 Cadmium content in root (A) and shoot (B) of garlic

The plant material was treated with $0,1,2,5,7$ and $10 \mathrm{mmol} \cdot \mathrm{L}^{-1} \mathrm{CdCl}_{2}$ for $6,12,36$ and $72 \mathrm{~h}$, and 6 days separately. The cadmium content was determined by atomic absorption spectrometry. Values correspond to means $\pm S E$ of three samples, and the data are significantly different at the level of $p \leqslant 0.05$ 

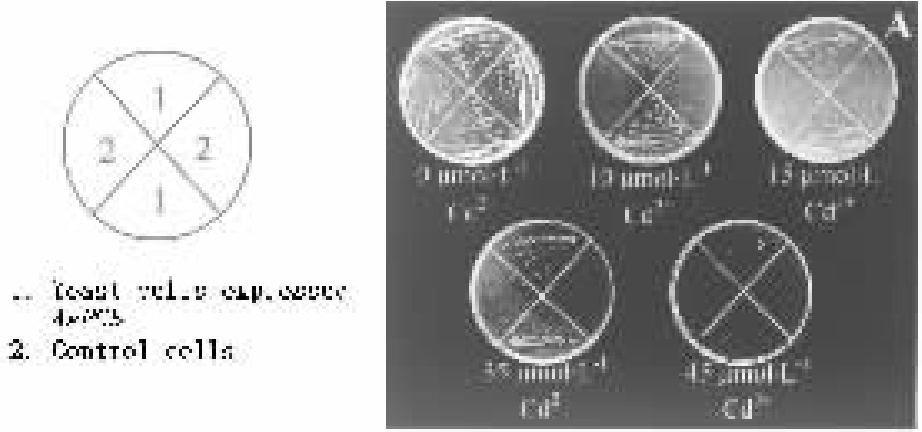

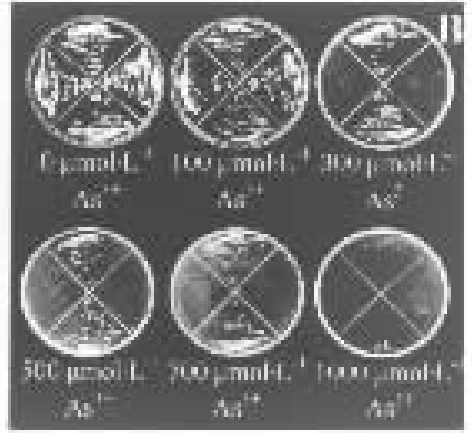

Fig.2 Expression of AsPCS increased the tolerance of yeast cell to $\mathrm{Cd}^{2+}$ and $\mathrm{AsO}_{2}{ }^{-}$

A: ABDE-1 and ABDE-1/AsPCS growing in YPD plates containing different $\mathrm{CdCl}_{2}$ concentrations B: FD236-6A and FD236-6A/AsPCS growing in YPD plates containing different $\mathrm{AsO}_{2}{ }^{-}$concentrations
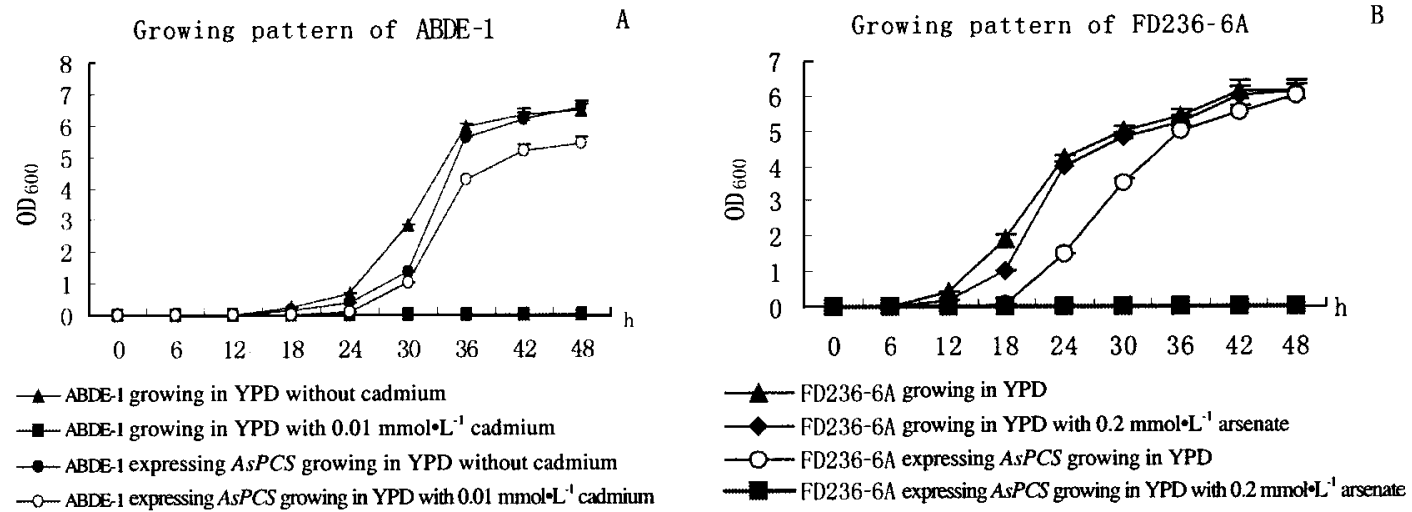

- ABDE-1 growing in YPD without cadmium

- $\mathrm{ABDE}-1$ growing in $\mathrm{YPD}$ with $0.01 \mathrm{mmol} \cdot \mathrm{L}^{-1}$ cadmium

$\rightarrow$ ABDE-1 expressing AsPCS growing in YPD without cadmium

-1- ABDE-1 expressing AsPCS growing in YPD with $0.01 \mathrm{mmol} \cdot \mathrm{L}^{-1}$ cadmium

Fig.3 AsPCS-expressing cells grow well in liquid YPD in the presence of $\mathrm{Cd}^{2+}(\mathrm{A})$ and $\mathrm{AsO}_{2}{ }^{-}(\mathrm{B})$, which can completely inhibit the control cells Values correspond to means $\pm S E$ of three samples.

A

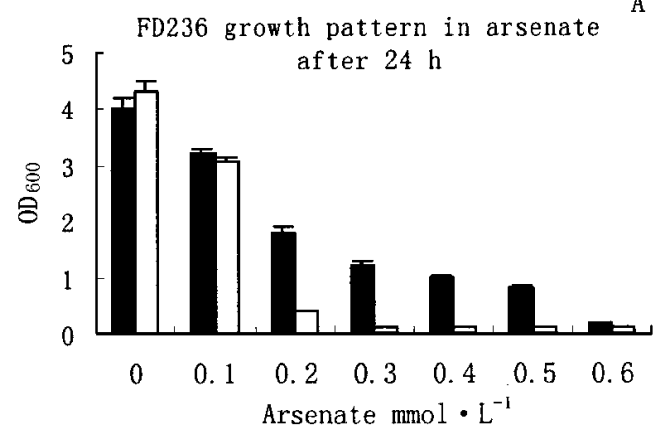

FD236-6A expressing AsPCS in YPD with arsenate 口FD236-6A in YPD with arsenate

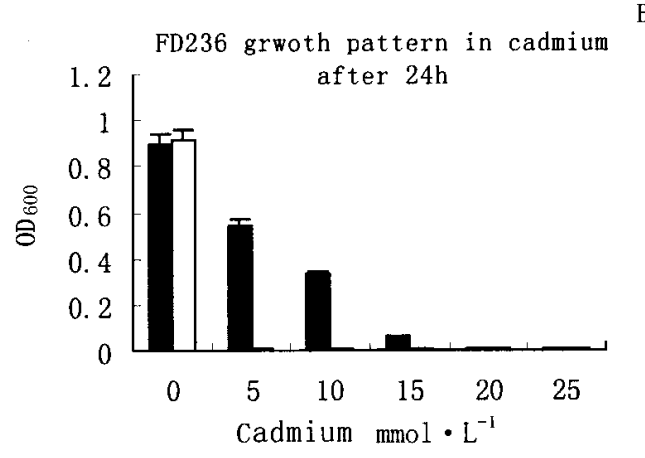

FD236-6A expressing AsPCS in YPD with cadmium 口FD236-6A in YPD with cadmium

Fig.4 An AsPCS-expressing cell displays a strong degree of $\mathrm{Cd}^{2+}$ and $\mathrm{AsO}_{2}{ }^{-}$tolerance after growing in liquid YPD containing a high concentration of $\mathrm{Cd}^{2+}$ and $\mathrm{AsO}_{2}{ }^{-}$for $24 \mathrm{~h}$

Values correspond to means $\pm S E$ of three samples, and the data are significantly different at the level of $p \leqslant 0.05$ 
$4 B)$.

\section{Discussion}

Garlic can tolerate a higher $\mathrm{Cd}^{2+}$ concentration than $\gamma$-ECS-overexpressing Indian mustard ( Zhu et al., 1999). Like Indian mustard, in despite of the high cadmium concentration in the roots, garlic can accumulate less cadmium in its shoots even when treated by a higher cadmium concentration (Fig. 1). This result indicated that the main location for cadmium accumulation in garlic is roots. This means that garlic is a phyto-stabilisation plant rather than a phyto-extraction plant. So garlic is one of the best research materials in the quest to understand the molecular mechanisms of plant for heavy metal binding, and one of the best sources for cloning the genes to apply in phytoremediation.

We cloned a new full-length cDNA of PC synthase gene from garlic (data not shown). Its expression allows yeast cells to tolerate a concentration of $\mathrm{Cd}^{2+}$ and $\mathrm{AsO}_{2}{ }^{-}$ that is over 3-fold higher than that tolerated by control cells (Fig. 2). The results indicated that AsPCS could respond to different heavy metals. AsPCS-expressing cells continue to display a strong degree of $\mathrm{Cd}^{2+}$ and $\mathrm{AsO}_{2}{ }^{-}$ tolerance after growing in liquid YPD containing a high concentration of $\mathrm{Cd}^{2+}$ and $\mathrm{AsO}_{2}{ }^{-}$for $24 \mathrm{~h}$ (Fig. 3). This suggests that, just as PC synthase works with $\mathrm{Cd}^{2+}$ (Clemens et al., 1999), AsPCS also plays a catalytic role in $\mathrm{AsO}_{2}{ }^{-}$resistance instead of binding directly to it. Marcus et al. (2000) showed that arsenite and arsenate binding PCs could be formed under the stress of arsenicals and that As anions could induce the biosynthesis of PCs. The enhancement of $\mathrm{AsO}_{2}{ }^{-}$tolerance for yeast when expressing AsPCS showed that the expression of AsPCS was increased under the stress of As, and led to improved synthesis of PC, which could bind much of the As anions.

Although As anions could improve PCs activation (Marcus et al., 2000), after comparing the growth of AsPCS expression in yeast cells and control cells, we reached the conclusion that the high expression of $A s$ $P C S$, rather than the enzymatic activation improvement, played a major role in As tolerance for yeast. Moreover, the expression of AsPCS improved the yeast's death concentration about 4-fold higher for cadmium and 2-fold higher for arsenite (Fig. 4). This indicated that AsPCS was more efficient for cadmium tolerance than for arsenite. Wysocki et al. (2003) showed that the TaPCS that came from wheat made acr3 yeast tolerant to $0.1 \mathrm{mmol}$ $\mathrm{L}^{-1}$ arsenate, while what interested us most are our results showed that the AsPCS could improve the concentration to $1 \mathrm{mmol} \cdot \mathrm{L}^{-1}$. Unlike $T a P C S, A s P C S$ coming from a heavy metal tolerant plant is more useful to phytoreme- diation through its much higher arsenate tolerance.

In order to investigate the roles of $A s P C S$ in tolerance to other heavy metals, we also tested the growth of $A s P C S$-expression yeast under the stress of $\mathrm{Cu}^{2+}$ (data not shown). We found that the AsPCS-expression cells didn' $t$ show higher tolerance to $\mathrm{Cu}^{2+}$ than the control, compared to metallothionein cDNA from another heavy metal tolerant plant, Festuca rubra (Ma et al., 2003). Lee et al. (2003) reported that PC was not a major factor in $\mathrm{Cu}$ tolerance of plants, and our studies give additional evidence to support this conclusion.

As a new method to clear heavy metal pollution, phytoremediation shows a bright future in this field. Big biomass and strong heavy metal binding ability are two conditions for phytoremediation. Our study provides such a useful gene element for the heavy metal binding ability . Combining with the transgenic technique, the AsPCS could be developed to a good tool for cleaning of heavy metals.

\section{Reference}

Clemens S, Kim EJ, Neumann D, Schroeder JI (1999) . Tolerance to toxic metals by a gene family of phytochelatin synthases from plants and yeast. The EMBO Journal, 18, 3325-3333.

Ecker DJ, Butt TR, Sternberg EJ, Neeper MP, Debouck C, Gorman JA, Crooke ST (1986). Yeast metallothionein function in metal ion detoxification. Journal of Biological and Chemistry, $261,1689-1690$.

Goyer RA (1997). Toxic and essential metal interaction. Annual Review of Nutrition, 17, $37-50$.

Jian SG(简曙光), Yang ZY (杨中艺) (2002). The role of stem nodule in the adaptation of Sesbania rostrata to $\mathrm{Pb} / \mathrm{Zn}$ tailings environment. II. The effect of stem nodule on nitrogen and heavy metals accumulation of Sesbania rostrata. Acta Phytoecologica Sinica (植物生态学报), 26, 209-215. (in Chinese with English abstract)

Lee S, Petros D, Moon JS, Ko TS, Goldsbrough PB, Korban SS (2003) . Higher levels of ectopic expression of Arabidopsis phytochelatin synthase do not lead to increased cadmium tolerance and accumulation. Plant Physiology and Biochemistry, 41, 903 -910 .

Ma LQ, Komar KM, Tu C, Zhang W, Cai Y, Kennelley ED (2001). A fern that hyperaccumulates arsenic. Nature, 409, 579 .

Ma M, Lau PS, Jia YT, Tsang WK, Lam SKS, Tam NFY, Wong YS (2003). The isolation and characterization of Type 1 metallothionein (MT) cDNA from a heavy-metal tolerant plant, Festuca rubra cv. Merlin. Plant Science, 164, 51-60.

Marcus EV, Schmöger MO, Grill E (2000). Detoxification of arsenic by phytochelatins in plants. Plant Physiology, 122, $793-$ 802 .

Meharg AA, Hartley-Whitaker J (2002). Arsenic uptake and 
metabolism in arsenic resistant and nonresistant plant species. New Phytologist, 154, 29 - 44.

Minet M, Dufour ME, Lacroute F (1992). Complementation of Sccharomyces cerevisiae auxotrophic mutants by Arabidopsis thaliana cDNAs. Plant Journal, 2,417-422.

Rauser WE (1999). Structure and function of metal chelators produced by plants: the case for organic acids, amino acids, phytin and metallothioneins. Cell Biochemistry and Biophysics, 31, 19 -48 .

Salt DE, Smith RD, Raskin I (1998). Phytoremediation. Annual Review of Plant Physiology and Plant Molecular Biology, 49, 643 -668 .

Stohs SJ, Bagchi D (1995) . Oxidative mechanisms in the toxicity of metal ions. Free Radical Biology Medicine, 18, 321 - 336.

Wei CY(韦朝阳), Chen TB(陈同斌) (2002). The ecological and chemical characteristics of plants in the areas of high arsenic levels. Acta Phytoecologica Sinica (植物生态学报), 26, 695 700. (in Chinese with English abstract)

Wysocki R, Bobrowicz P, Ul' aszewski S (1997). The Saccha- romyces cerevisiae ACR3 gene encodes a putative membrane protein involved in arsenite transport. Journal of Biological Chemistry, 272, $30061-30066$.

Wysocki R, Clemens S, Augustyniak D, Golik P, Maciaszczyk E, Tamás MJ, Dziadkowiec D (2003). Metalloid tolerance based on phytochelatins is not functionally equivalent to the arsenite transporter Acr3p. Biochemical and Biophysical Research Communications, 304,293-300.

Zhang YX (张玉秀), Chai TY (柴团耀), Burkard G (1999). Research advances on the mechanisms of heavy metal tolerance in plants. Acta Botanica Sinica (植物学报), 41,453-457. (in Chinese with English abstract)

Zhou JM, Goldsbrough PB (1994). Functional homologs of fungal metallothionein genes from Arabidopsis. The Plant Cell, 6,875 -884 .

Zhu YL, Pilon-Smits EAH, Jouanin L, Terry N (1999). Overexpression of glutathione synthetase in Indian mustard enhances cadmium accumulation and tolerance. Plant Physiology, 119,73 -80 . 